\title{
Непрохідність тонкої кишки. Спірні питання щодо дренування травного
}

\author{
каналу \\ V. V. BENEDYKT \\ SHEI "Ternopil State Medical University by I. Ya. Horbachevsky"
}

\section{OBSTRUCTION OF THE SMALL INTESTINE. CONTROVERSIAL ISSUES CONCERNING THE DRAINING OF THE ALIMENTARY CANAL}

\begin{abstract}
Лікування гострої непрохідності кишки супроводжусться високою летальністю і залишасться складним у плані вибору лікувальної тактики. В клінічних умовах обстежено 122 хворих на ГНК. Проведено ретроспективний аналіз 27 медичних карт стаціонарного хворого померлих пацієнтів. Причиною летального наслідку в 77,78 \% випадків був синдром поліорганної недостатності. Назогастроінтестинальна інтубація у цих хворих була виконана у 60,0 \% прооперованих і у 20,0 \% паціснтів під час релапаротомії. Дренування тонкої кишки за допомогою кінцевих стом під час релапаротомій використовували в 30,0 \% померлих. У пацієнтів із ГНК в перші три доби після операції спостерігали суттєве зростання інтоксикаційного синдрому, показники якого зменшувалися після відновлення моторно-евакуаторної функції тонкої кишки. Наводяться клінічні випадки хворих на ГНК із різними способами дренування тонкої кишки. Запропоновано спосіб ентеростомії для дренування тонкої кишки. Наголошусться на необхідності ранньої стимуляції рухової діяльності травного каналу. Наводиться алгоритм застосування дренування тонкої кишки у хворих на гостру непрохідність кишки. Звертасться увага на необхідність врахування під час операції стадії компенсації основних функцій організму при цьому захворюванні.

Treatment of an acute intestinal obstruction is accompanied by high mortality and remains a difficult issue in the choice of treatment strategy. In the clinical setting, there were examined 122 patients with an acute obstruction of the intestine. A retrospective analysis of 27 in-patient medical records of deceased patients was conducted. The cause of the fatal cases in $77,78 \%$ of cases was multiple organ failure syndrome. In $60.0 \%$ of these patients was performed the nasogastrointestinal intubation and in $20,0 \%$ of patients during the relaparotomy. Drainage of the small intestine by the end Stom during the relaparotomiy was used in $30,0 \%$ of the dead.

In patients with an acute intestinal obstruction in the first three days after surgery there was a significant increase of intoxication syndrome which indicators decreased after restoration of motor-evacuation function of the small intestine. We give clinical cases of patients with different ways of draining the small intestine. The way of enterostomy for intestinal intubation was offered. There is stressed the need for early stimulation of motor activity of the alimentary canal. Attention is focused to the need to consider during the operation of the functional state of the main organs and systems in this disease. An algorithm of application of draining the small intestine in patients with an acute bowel obstruction depending on the condition of the small intestine and the patient is presented.
\end{abstract}

Постановка проблеми і аналіз останніх досліджень та публікацій. 3 усіх гострих хірургічних захворювань органів черевної порожнини гостра непрохідність кишки (ГНК) спричиняє найбільшу летальність $[2,6,15]$. Головною причиною $\epsilon$ несвоєчасна діагностика [2]. Втім, це жодною мірою не зменшує значення вибору адекватної хірургічної тактики під час операції. Звільнення тонкої кишки (ТК) від ії̈ вмісту під час операції та створення безперешкодного його відтоку в післяопераційному періоді досягається інтубацією цього органа. Питання вибору того чи іншого способу декомпресії ТК під час операції у хворих на ГНК остаточно ще не вирішено. Так, деякі автори [11] категорично проти відкритих способів декомпресії. В. Т. Зайцев і співавт. (1989) [7] до методів декомпресії висувають такі вимоги: максимально повне звільнення кишки від $\dddot{1}$ вмісту, попередження інфікування черевної порожнини, можливість ефективного видалення вмісту в післяопераційному періоді, мінімальна травматизація ТК під час інтубації. Переваги різних методів дренування ТК дискусійні. Майже жоден із них не відповідає цим вимогам.

Мета роботи: визначення варіантів клінічних ситуацій у хворих на ГНК для вибору диференці- 
йованого підходу до декомпресії ТК, що покращить результати лікування цих пацієнтів.

Матеріали і методи. У клінічних умовах обстежено 122 хворих на ГНК. Проведено ретроспективний аналіз 27 медичних карт стаціонарного хворого померлих пацієнтів. Причиною ГНК були спайкова хвороба очеревини, защемлені грижі, обтурація просвіту жовчними каменями та інші доброякісні захворювання. Досліджували тяжкість інтоксикаційного синдрому за лейкоцитарним індексом інтоксикації (ЛІІ) [8], концентрацією молекул середньої маси (МСM) [3], неспецифічну резистентність організму - за паличкоядерно-лімфоцитарним індексом (ПЛІ) [1].

Результати досліджень та їх обговорення. При проведенні ретроспективного аналізу померлих пацієнтів було встановлено, що тільки 4 (14,81%) хворих госпіталізовано в першій стадії перебігу захворювання, в другій - $14(51,85 \%)$ і в третій - 9 (33,33 \%). При дослідженні ступеня компенсації функціонального стану цих пацієнтів [8] декомпенсацію спостерігали в 17 (62,96 \%) хворих. Назогастроінтестинальну інтубацію було виконано 15-ти $(60,0 \%)$ прооперованим хворим і в $2(20,0 \%)$ пацієнтів під час релапаротомії. Дренування тонкої кишки за допомогою кінцевих стом під час релапаротомій проведено в 3 (30,0 \%) випадках. Шести пацієнтам виконано 10 релапаротомій. Причиною летального наслідку в $21(77,78 \%)$ пацієнта був синдром поліорганної недостатності, у 5 $(18,52 \%)$ хворих - декомпенсація серцево-судинної системи і у 1 (3,70 \%) пацієнта - емболія легеневої артерії. У цій групі досліджених відсутність перистальтики кишки спостерігали в $22(81,48 \%)$ хворих, а іiї пригнічення - в $6(22,22 \%)$, що вже сприяло підсиленню інтоксикації. У всіх хворих було виявлено значний ступінь інтоксикації та зниження неспецифічної резистентності організму, що зумовлює пік летальності в першу (16,0\%) і третю $(28,0 \%)$ доби після операції із загальною летальністю в перші три доби до $56,0 \%$ (рис. 1).

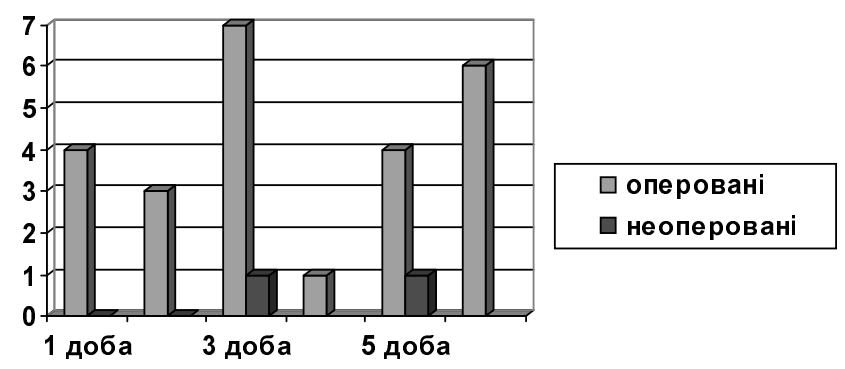

Рис. 1. Строки летальних наслідків у хворих на ГНК.
Серед померлих хворих на ГНК основною причиною $є$ синдром інтоксикації, зумовлений порушеннями функції травного каналу. Однією з причин такого стану, на нашу думку, $є$ виконання під час оперативного втручання неадекватного методу декомпресії травного каналу. Найбільш бережним і досить ефективним способом декомпресії тонкої кишки (ТК) є назогастроінтестинальна інтубація $[12,13$, 14]. Водночас дані літератури $[6,14]$ і наш клінічний досвід засвідчують випадки неефективного дренування ТК цим методом у післяопераційному періоді, що пояснюється антиперистальтичною евакуацією вмісту кишки та ін.

При проведенні ретроспективного аналізу цієї групи хворих виникають такі запитання. Чи завжди необхідно проводити дренування ТК у хворих на ГНК? Який спосіб інтубації вибрати при наявності абсолютних показань до дренування ТК у хворих на ГНК?

Наводимо результати наших досліджень у хворих на ГНК.

У пацієнтів на ГНК значення ЛІІ до операції складало $(2,91 \pm 0,13)$ од., і мало місце збільшення його величини в першу і третю доби після операції в 1,5 та 1,3 раза відповідно. Тільки на 6-8-му добу величина ЛІІ досягала нормального значення. Концентрація МСМ у пацієнтів цієї групи складала $(0,355 \pm 0,049)$ оп. од. На 1-шу добу після операції спостерігали суттєве підвищення їх концентрації (на $31,5 \%$ ) з поступовим зменшенням - 3 5-ї доби і нормалізацією - на 6-8-му добу післяопераційного періоду. У хворих, оперованих з приводу ГНК, поява кишкових перистальтичних звуків була зареєстрована у $61,5 \%$ спостережень на 1-2-гу добу після операції, а відходження газів мало місце у 80,3 \% пацієнтів тільки на 3-5-ту добу після операції і в усіх - до кінця 7-ї доби.

Вибір способу дренування травного каналу у хворих на ГНК вимагає від хірурга прийняття нестандартних рішень під час операції. При наявності абсолютних показань до інтубації ТК і неможливості проведення назогастроінтестинального зонда ми пропонуємо наш спосіб ентеростомії (рис. 2) [4].

Спосіб ентеростомії здійснюють таким чином. Петлю ТК з'єднують між собою серо-серозними швами на відстані 6-8 см у вигляді двостволки. Роблять на них два паралельних розрізи довжиною до 4 см. У необхідному напрямку в ТК вводять дренувальну трубку. Дистальний кінець цієї трубки занурюють між анастомозуючими ділянками за допомогою серо-серозних вузлових швів (рис. 2 , А, Б), а в ділянці ентеротомій накладають ентеро-ентероанастомоз. “Сліпий” кінець цієї петлі підшива- 
ють до парієтальної очеревини за допомогою вузлових швів (рис. 2, В).

На основі проведених досліджень ми розробили такий алгоритм для дренування ТК (рис. 3).
Висновки. 1. Гостра непрохідність тонкої кишки є нестандартним захворюванням, яке потребує неординарних підходів до дренування тонкої кишки під час оперативного втручання.

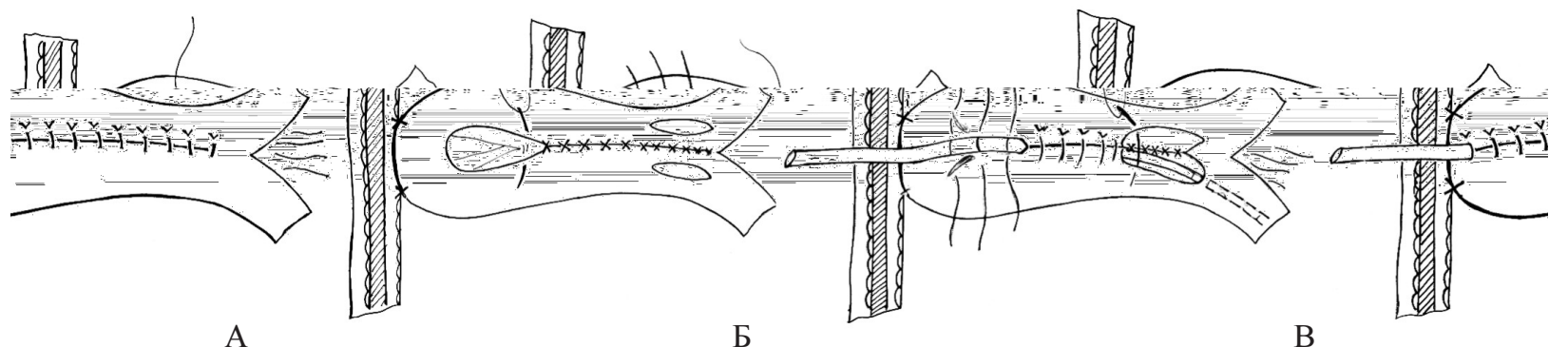

Рис. 2. Схема запропонованої ентеростоми з дренуванням тонкої кишки.

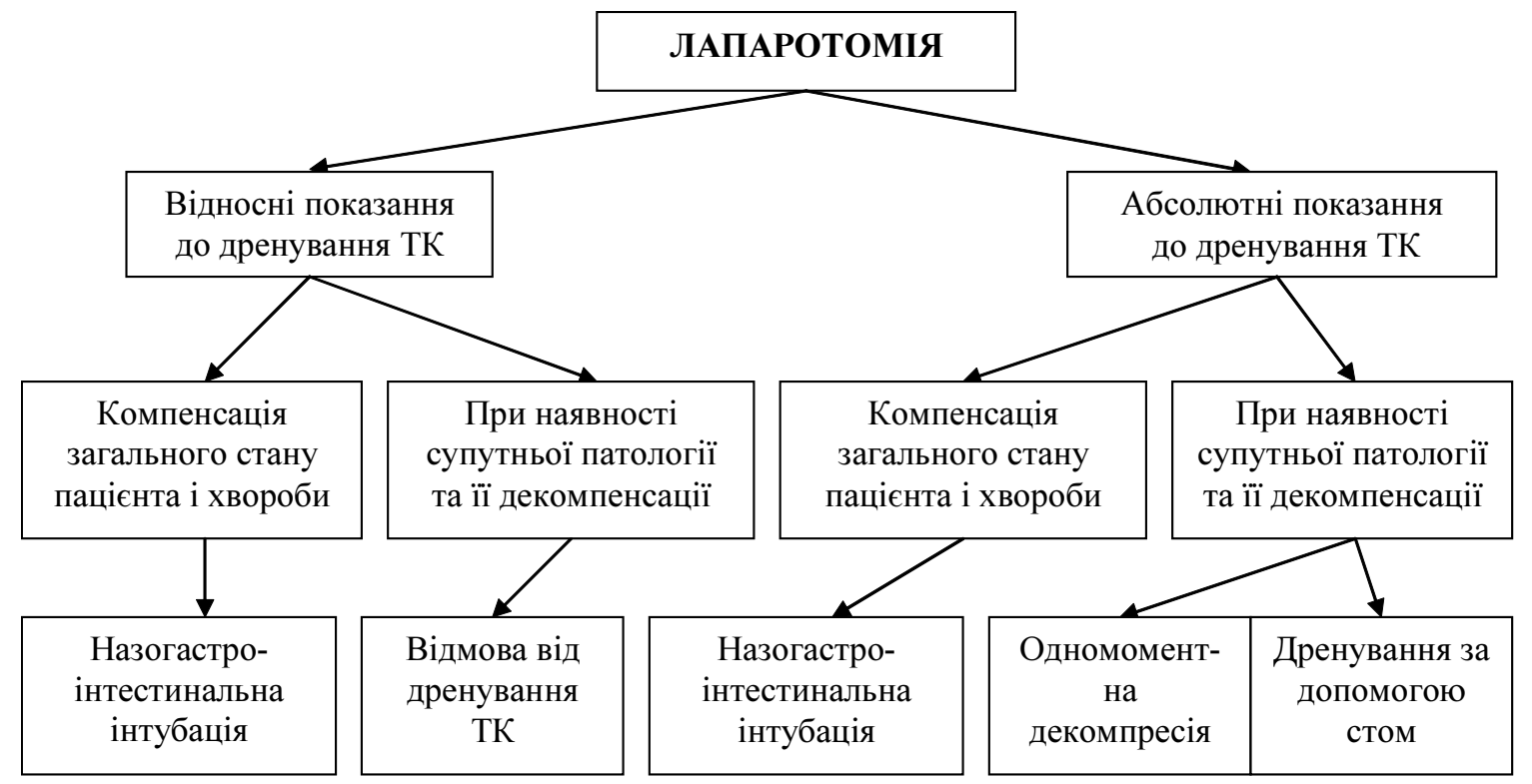

Рис. 3. Алгоритм вибору способу і показань до дренування тонкої кишки.

2. У хворих на гостру непрохідність кишки для вирішення питання про вибір методу декомпресії тонкої кишки необхідно враховувати не

\section{СПИСОК ЛІТЕРАТУРИ}

1. Бенедикт В. В. Особливості змін показників неспецифічної резистентності організму у хворих на перитоніт / В. В Бенедикт, М. С. Гнатюк, Ю. М. Голда // Здобутки клінічної та експериментальної медицини. - Тернопіль : Укрмедкнига, 2002. - С. 65-66.

2. Березницький Я. С. Уніфікація формування клінічного діагнозу та надання медичної допомоги в невідкладній колопроктології / Я. С. Березницький, В. В. Гапонов, В. П. Сулима // Харківська хірургічна школа. - 2009. - № 2.2. - С. 9-11.

3. Габриэлян Н. И. Диагностическая ценность определения средних молекул в плазме крови при нефрологических заболеваниях / Н. И. Габриэлян, А. А. Дмитриев, Г. П. Кулаков // Клиническая медицина. - 1981. - № 10. - С. 38-42.

4. Деклараційний патент на винахід № 55573 Спосіб ентеростомії / В. В. Бенедикт. - 2003. - Бюл. № 4. тільки стан тонкої кишки, а й стадії компенсації основних функцій організму при цьому захворюванні.

5. Деклараційний патент на винахід № 61258 А61 К33/06А Спосіб стимуляції моторної функції кишки в ранньому післяопераційному періоді / Л. Я. Ковальчук, І. О. Дячук, В. В. Бенедикт. - 2003. - Бюл. № 11.

6. Ерюхин И. А. Кишечная непроходимость : руководство для врачей // И. А. Ерюхин, В. П. Петров, М. Д. Ханевич. - СПб. : Питер, 1999. - 448 с.

7. Неотложная хирургия брюшной полости / [В. Т. Зайцев, В. Е. Алексеенко, И. С. Белый и др.]. - К. : Здоров'я, 1989. $272 \mathrm{c}$.

8. Кальф-Калиф Я. Я. О гематологической дифференциации различных форм и фаз острого аппендицита / Я. Я. КальфКалиф // Хирургия. - 1947. - № 7. - С. 40-43.

9. Ковальчук Л. Я. Гостра непрохідність кишки. Особливості діагностично-лікувальної програми на етапах лікування / 


\section{з ДОСВІДУРОБОТИ}

Л. Я. Ковальчук, І. Я. Дзюбановський, В. В. Бенедикт // Матеріали міжобласної наук.-практ. конф.

"Гостра непрохідність кишечника" / за ред. проф. Ю. С. Семенюка. Рівне-Харків-Тернопіль, 2006. - С. 70-83.

10. Милюков В. Е. Патогенез метаболических нарушений при динамической кишечной непроходимости / В. Е. Милюков // Российский журнал гастроэнтерологии, гепатологии, колопроктологии. - 2006. - № 6. - С. 70-72.

11. Моше Шайн. Здравый смысл в неотложной абдоминальной хирургии / Моше Шайн ; пер. с англ. под ред. Б. Д. Савчука. - М. : ГЭОТАР-МЕД, 2003. - 272 с.
12. 50 лекций по хирургии / под ред. В. С. Савельева. - М. : Медиа Медика, 2003. - 408 с.

13. Радзиховский А. П. Релапаротомия / А. П. Радзиховский, О. Е. Бобров, А. А. Ткаченко. - К. : Феникс, 2001. - 360 с.

14. Томашук И. Т. Методы интубации кишечника при острых перитонитах / И. Т. Томашук //Анналы хирургической гепатологии. - 1998. - № 3. - С. 360-362.

15. Тотиков В. 3. Лечебно-диагностическая программа при острой спаечной обтурационной тонкокишечной непроходимости / В. 3. Тотиков, М. В. Калицова, В. М. Амриллаева // Хирургия. - 2006. - № 2. - С. 38-43.

Отримано 12.12.12 